\title{
RENAISSANCE AND REFORMATION
}

\section{CONTEMPORARIES BUT NOT ALLIES}

Van der Walt, B. J. MA, Th.B, D.Phil

I do hope that you are going to have the deepest appreciation for my contribution, because it really represents an attempt at the impossible. To force a whale into a sardine tin is no mean feat, and here one is expected to force four whales (Renaissance, Humanism, the Stoa and Calvin) into the same tin. The titanic effort assumes even more heroic proportions when one considers that I have exactly ten minutes at my disposal in which to commit this academic crime.

Calvin as a reformer (the theme of the congress) can only be fully understood and really appreciated if the background against which he grew up, developed, though and wrote is also carefully considered.

The sixteenth century décor against which his life played itself out is an extremely complex and many-sided one. There is an unbelievably wide range of factors which we have to keep in mind in the field of the church and religion, in the field of society and politics, and in the field of philosophy and theology.

There is a great deal of variation within each of the three trends that we are going to deal with. Apart from that there is a strong degree of recipprocation among the various trends: Renaissance, Humarism and Stoicism can only be dissected neatly in the quiet of the study.

In what follows I am merely going to attempt to isolate the most inisistent religious driving force behind the Renaissance and the Reformation.

\section{THE SIXTEENTH CENTURY: A SPIRITUAL WATERSHED}

The turmoi! in a number of areas was already noticeable in the late Middle Ages. The sixteenth century became an uneasy period of "Sturm und Drang" with many far-reaching events: repeated epidemics of the plague, agrarian and economic crises and largescadle urbanization with the resultant social upheaval.

A new mercantile middle class was established, and the farmers rebelled against injustices.

This was also, however, a period of unprecedented broadening of horizons. Apart from the compass and gunpowder, manuscripts of great age were also discovered and studied. Through the voyages of discovery the world map was extended, the use of paper and of mobile printing, the origin of schools and the development of the universities, new ideas (such as those of Copernicus) all heralded the birth of a new world.

And the spiritual ieaders were aware of this dawning. Over against the dark Middle Ages they began to see their own epoch as a golden epoch, a new epoch of light and enlightenment. 
In the dawning of the new era in Western cultural history various inteliectual trends came into being. each with the pretension of having the light to shed, each secure in the belief that he and he only could offer new certainty and security to European man.

Whoever attunes his seismograph sensitively and carefully obseves what went on, would see clearly that the ways diverged here. The sixteenth century represents the beginning of the end of the important role that Christendom played in the West for a millenium $( \pm 500- \pm 1500)$. At his time the secularisation of the West originated. A new paganism was born. At first it was a little unsteady, and sleepy-eyed, but it would soon capture the West by storm.

In spite of the mutual dissatisfaction with the Scholastic past the ways slowly but clearly diverged. The Renaissance broke with the mentality of synthesis, because it could not tollerate the Christian and Biblical element contained in it. For the Reformation the synthesis between Christendom and pagan throught became unacceptable because the World of God did not come to full justice in it.

As to the question at which source one should look for light in the new epoch there is little unanimity. One could call the Renaissance the light-bearer of Cain and the reformation the light-bearer of Obel.

\section{THE RENAISSANCE: LIGHT-BEARER OF CAIN}

We can already discern the difference in the early or so-called Christian Humanism and the thinkers of the pre-Reformation. Both sought to kindle their own flame at the Patristic age. The motives, however, differed. The precursors of the Reformation return to Patristic thuught, because they are fascinated by the Scriptural aspecis of it, while early humanist thought is more interested in the question as to how the early Christian thinkers could simultaneously also be Romans!

This early form of Humanism was mainly a pedagogical movement which .ought a moral injection to effect rebirth of church and religion in the past.

Later Humanism still sought to redream the beautiful ideals of the past. These thinkers, however, delved deeper into the past. The period to which they returned to kindle their light was not so much the Patres as the Greek and Roman periods of antiquity.

Here we have a still clearer leftish trend. The question now is not so much (as with the early Humanists) how it is possible to be simultaneously Christian and Roman, but why it is not possible (as in antiquity) to be purely Roman (that is pagan) in thought. The emancipation from church and religious bonds strengthened. Autonomous, assured, dignified and noble man emerged ever more clearly.

Humanism was characterized by a scientific, literary and educational ideal based on a study of Antiquity. (It was more confined to the intellectuals as against the Reformation whitch was a more popular movement.) Humanism was the result of the process of fermentation instigated by the Renaissance in the field of the sciences. It did not, however, consist merely of the grouping of a number of 
disciplines. A new vision of life was presupposed in it. In his view of life the Humanist dreamt not only of a number of disciplines but also of the end result of schooling therein: a new world in which the new, autonomous man would be dominant.

Al: too soon the Humanists began to realize that while a glorious past could be recreated in dreams, dreaming within the study alone was not adequate to build a new culture. Repristination, after all, did not seem to hold the true answer. The clock of history could not be reset at will.

Too much stress on the authority of the writers of Antiquity, for example, checked originality. And noble man could not be inhibited thus!

Renaissance man (and you might notice that I do not distinguish sharply between Humanism and the Renaissance) thus took a further step: Man could be reborn of his own power. Man did not need the midwife of Christianity any more than that of pagan Antiquity. Man could pull himself up by his own bootstraps and be the source of his own light.

One of the antique trends which beautifully complemented the new spirit of Renaissance man was Stocism, as represented in Antiquity by figures such as Cicero and Seneca. This was a school of thought in which man and his imperturbable moral duties stood in the centre. Renaissance intellectuals liked the doctrine of back to nature (in the place of the Scriptural one of grace). The Stoa, however, did not find the Laws for moral life (logoi spermatikoi of the Logos) only in nature. These laws or measuring rods they considered to be implanted in the reasoning faculty of man. Man was thus basically his own lawgiver, and autonomous. Rationalism, seminally already present in the Antique Stoa, was eagerly embraced by Renaissance man and would soos assume a leading role in the Western world.

As a result of the initial trend to return to the past, a number of other Aritique schools of thought (such as neo-Platonism, Aristotelianism, Pythagoreism, Epicurism and Scepticism) had revivals in the course of the fifteenth and sixteenth centuries. We cannot go into all these. We have to direct our attention now to a totally different group which found their light for a new epoch else where.

\section{THE KEFORMATION: LIGHT-BEARER OF ABEL}

The reformers were also sick of the scholastic synthetic thought. They broke with it, however, for the exact opposite reason than the Renaissance did, viz. to enable the Word to God to be freed again. Their thought can be regarded as being clearly anti-synthetic to the right.

The reformers learnt a great deal from Antiquity. Like the "precursors of the Reformation" they also returned in many respects to the Church Fathers. The motive, however, lay in the fact that they could be regarded as representing a purer period in the history of Christendom. Thus Augustine was for Calvin in the first place a guide back to the Word of God.

The Reformation clearly sought its source of light elsewhere. 
It did not look at pagan Antiquity; it did not look at the enlightened, noble, educated man some of age and reborn through his own devising, who followed the light of his own intellect. Whether one sought authorily from the Pope or from enlightened man was in the eyes of the Reformers equally wronng.

Iight for them emanated not from the earth but from Above. The Refcrmation sought not merely historical change on the horizontal level, but religious change on the vertical level of the relationship of man to God and his Law; not conversion to the past or reaction against the past or conversion from one's own power, but conversion to God and to his Word. Absolute authority belonged to God alone. The Word is the only source of light.

\section{CALVIN PUTS TO THE TEST THE SPIRIT OF THE TIMES}

It would be wrong - as many are so prone to do - to regard Calvin, out of a sense of piety, as a sort of sixteenth century Melchisedek: a man without beginning or background. He grew up within a certain perind and was in many respects a child of his time. From his youth onwards he came into daily contact with all the spiritual trends of his eniironment. One could even say that his own thinking developed out of a continuing polilogue that he conducted with the various trends of thought current in his lifetime.

It wculd be wrong to try to explain Calvin's philosophies merely from extra-Biblical influences. It would be equally wrong, however, to claim that he underwent no influence other than the Bible.

A few remarks regarding Calvin and Humanism, the Stoa, and Platonism should serve to illustrate this.

Humarism. According to experts, Calvin was influended especially by that type of Humanism in which Philology, as a result of the literary renaissance, played an important role. This group in their reversion to the sources, developed a specific historical philological method which prescribed an attitude of reverence towards the antique texts. The historical awareness and the effort to be objective towards the sources and to let them speak for themselves was a novelty.

Calvin had a lot to thank, Humanism for in this respect. He assumed a cimilar attitude to the Scriptures. It was an enormous forward step that in his exegesis of the Scriptures he broke with the centuries-old allegorical exegesis, because this had been an important method for reading all sorts of foreign ideas into the Bible and hus effecting a synthesis between Scripture pagan concepts.

Stoicusm. The fact that Calvin's very first writing was a commentary on Seneca's De Clementia, would seem to indicate just how intimately he was aware of this school of thought. Some would suggest that Calvin's thought was in fact none other than "baptized Stoicism". The other extreme is also represented by those who would plead that there is no evidence whatsoever of Stoic influence on Calvin.

One cuuld, of course, use the concept "influence" in different ways. Personally, I find definite and clear influence of the Stoa on 
Calvin's idea of a lex naturalis and, concurrently, his idea of a semen religronis and conscientia (conscience).

Platonism. In research in this field one has to do with two extreme viewpoints. Where some sin by omission (per defectum) by maintaining that Plato had put aside completely the Platonising tendency (of Augustine, for example), others sin as it were by commission (par exessum) by totally over-estimating the influence of Platonism on Calvin.

My own tentative researches in this field have convinced me that Calvin's thought underwent influence from Plato and the neoPlatonists not only in the formal sence of word usage but also in the contesiual sense (as regards content). His view of man is perhaps the clearrest evidence of this.

I vould not, however, go so far as to call Calvin a Platonist. That would presuppose a relationship of master and scholar which in this case definitely did not exist. What Calvin found useful in Plato he used - without becoming a disciple intent on confirming his master's ideas and careful that not one fact of it be changed.

\section{RECAPITUL.ATION}

The Renaissance, with all the philosophical schools it enabled to revive in the sixteenth century, was at heart a religious movement to the left, away from the Word of God and the God of the Word. Calvin's religious bias was to the right. He was inbued by a different spirit.

For that reason one has to be very careful not to come to the conclusion that Calvin was influenced by a specific philosophical school merely on the basis of similar word usage and parallel intellectual patterns. A more searching analysis is necessary in which the relevant systems (eg. the entire anthropology) can be fully and carefully compared.

In general it might be said that Calvyn did not take the philosophical material of his times too seriously. He normally dealt with it in a remarkably nonchalant manner. His use of the philosophical ideas of his time is more historical than systematic. He used it as an illustration of the truth rather than as a guide to the truth. His thought was not carried by these ideas, but these ideas did contribute to the clarification and explication of what he was trying to say.

For that reason his use of Humanism, Stocism and Platonism can be said to be eclectic rather than systematic. As far as I now. one finds no attempt in his work of a sustained systematic argumentation to deal with a specific philosophy fully and to argue in its favour.

All of this, however, does not take away the fact that Calvin did, as regards some of his ideas (such as his concept of natural law and his anthropology) immersed himself deeply in the philosophies of his time. Whoever reads what Calvin wrote in an unbiased fashion in the light of the history of the epochs before him and of his own epoch would have to acknowledge this. 
Calvin's independence, however, is the most striking feature, guaranteed by the fact that the Source of this thought was the Word of God. Perhaps one should not revaluate Calvin negatively by the extent to which he submitted to extra-Biblical influences, but rather positively by inquiring to the extent to which he made a contributicn to our renewed better understanding of the Word of God.

Although it has not happened within the prescribed time limit, the clime has been committed and the whale is safely ensconced in the tin.

You see, Calvinism does not prevent one from sinning. The only thing is that it takes the enjoyment from the act of sin!

May I compound my crime by impertinence? If you should be interested to find out more about this topic, I would like to suggest that you obtain a copy of my publication Die denkdekor van die Reformasie. It is not so much that you will find this to be without sin, but that you will at least find the most important literature on the subject surveyed. 